\title{
Biosynthesis of gold nanoparticles by the extreme bacterium Deinococcus radiodurans and an evaluation of their antibacterial properties
}

This article was published in the following Dove Press journal:

International Journal of Nanomedicine

9 November 2016

Number of times this article has been viewed

\author{
Jiulong $\mathrm{Li}^{1, *}$ \\ Qinghao $\mathrm{Li}^{1}, *$ \\ Xiaoqiong $\mathrm{Ma}^{2}$,* \\ Bing Tian' \\ Tao Li' \\ Jiangliu Yu' \\ Shang Dai' \\ Yulan Weng' \\ Yuejin Hua'
}

'Key Laboratory for NuclearAgricultural Sciences of Chinese Ministry of Agriculture and Zhejiang

Province, Institute of NuclearAgricultural Sciences, Zhejiang University, ${ }^{2}$ Central Laboratory, The First Affiliated Hospital of Zhejiang Chinese Medical University, Hangzhou, China

*These authors contributed equally to this work
Correspondence: Bing Tian; Yuejin Hua Institute of Nuclear-Agricultural

Sciences, Zhejiang University, No 268,

Kaixuan Road, 310029 Hangzhou, China

Tel/fax +86 57। 8697 I2I5

Email tianbing@zju.edu.cn;

yjhua@zju.edu.cn

\begin{abstract}
Deinococcus radiodurans is an extreme bacterium known for its high resistance to stresses including radiation and oxidants. The ability of $D$. radiodurans to reduce $\mathrm{Au}(\mathrm{III})$ and biosynthesize gold nanoparticles (AuNPs) was investigated in aqueous solution by ultraviolet and visible (UV/Vis) absorption spectroscopy, electron microscopy, X-ray diffraction (XRD), dynamic light scattering (DLS), Fourier transform infrared spectroscopy (FTIR) and X-ray photoelectron spectroscopy (XPS). D. radiodurans efficiently synthesized AuNPs from $1 \mathrm{mM}$ $\mathrm{Au}(\mathrm{III})$ solution in $8 \mathrm{~h}$. The AuNPs were of spherical, triangular and irregular shapes with an average size of $43.75 \mathrm{~nm}$ and a polydispersity index of 0.23 as measured by DLS. AuNPs were distributed in the cell envelope, across the cytosol and in the extracellular space. XRD analysis confirmed the crystallite nature of the AuNPs from the cell supernatant. Data from the FTIR and XPS showed that upon binding to proteins or compounds through interactions with carboxyl, amine, phospho and hydroxyl groups, $\mathrm{Au}(\mathrm{III})$ may be reduced to $\mathrm{Au}(\mathrm{I})$, and further reduced to $\mathrm{Au}(0)$ with the capping groups to stabilize the AuNPs. Biosynthesis of AuNPs was optimized with respect to the initial concentration of gold salt, bacterial growth period, solution $\mathrm{pH}$ and temperature. The purified AuNPs exhibited significant antibacterial activity against both Gramnegative (Escherichia coli) and Gram-positive (Staphylococcus aureus) bacteria by damaging their cytoplasmic membrane. Therefore, the extreme bacterium $D$. radiodurans can be used as a novel bacterial candidate for efficient biosynthesis of AuNPs, which exhibited potential in biomedical application as an antibacterial agent.
\end{abstract}

Keywords: Deinococcus radiodurans, gold nanoparticles, gold ions, reduction, antibacterial

\section{Introduction}

Gold is one of the rarest metal elements in the earth's crust and occurs in aqueous solution as gold(0), gold(I) and/or gold(III) complexes. ${ }^{1,2} \mathrm{Au}$ ions can be reduced to inert gold nanoparticles (AuNPs). Compared with bulk gold materials, AuNPs with nanoscale size and morphological properties have unique characteristics including physical, chemical, electrical, mechanical, magnetic, optical and biological properties..$^{3,4}$ AuNPs have great potential in biomedical applications including drug delivery due to their pronounced biocompatibility, chemical inertness and physical properties. ${ }^{5-7}$

Traditionally, AuNPs are synthesized by physical or chemical processes which readily produce nanoparticles with controllable sizes and required chemical purity, which is of extreme importance in most of research or applications. However, consumption of high levels of energy during the physical process and use of plenty of chemicals as well as generation of potential hazardous waste during the chemical process limit the applications of these processes. ${ }^{8,9}$ The development of a biocompatible and ecofriendly 
biosynthetic process for AuNPs deserves merit. Biosynthetic process for nanoparticles using microorganisms and plants is receiving increasing attention due to its milder process condition and reduced use of toxic chemicals and has been suggested as a valuable alternative to physical and chemical methods. ${ }^{10}$ Growing evidence has highlighted the importance of microbial processes in the cycling of $\mathrm{Au} .{ }^{11} \mathrm{~A}$ number of microorganisms including bacteria, actinomycetes, archaea and fungi have been investigated for AuNPs synthesis. ${ }^{12}$ For example, Escherichia coli has been shown to precipitate $\mathrm{Au}(\mathrm{III})$ and subsequently transform it into AuNPs intracellularly and extracellularly from $\mathrm{AuCl}_{4}{ }^{-}$solution. ${ }^{13,14} \mathrm{Au}$ ions have toxic effects on organisms due to reactive oxygen species (ROS) generation as a result of $\mathrm{Au}(\mathrm{III})$ stress. $^{15,16}$ Moreover, in situ oxidants or highly active radionuclides may have adverse effects on microbial components such as cell surface functional groups and intracellular oxidoreductases and limit Au biotransformation. ${ }^{17}$ Hence, there is an increasing demand for the screening of microorganisms with both cell resistances to in situ stresses and effective AuNPs production ability.

Deinococcus radiodurans, a red-pigmented nonpathogenic bacterium isolated from an irradiated meat can, ${ }^{18}$ is well known for its exceptional resistance to radiation (15,000 Gy of ionizing radiation without lethality) and oxidants. The survival strategies of $D$. radiodurans are attributed to its efficient antioxidant and DNA repair systems. Its antioxidant system includes antioxidant enzymes and numerous smallmolecule ROS scavengers such as pyrroloquinoline-quinone, carotenoids and $\mathrm{Mn}^{2+}$ metabolite complexes, which might provide a reducing microenvironment for transformation or detoxification of heavy metals under in situ oxidative stresses. Moreover, the cellular envelope of D. radiodurans has a special composition and structure with at least six layers which include an outmost surface layer (S-layer) consisting of regularly packed hexagonal protein subunits. ${ }^{19,20}$ D. radiodurans was developed for the remediation of radioactive-mixed waste to reduce $\mathrm{Cr}(\mathrm{VI}), \mathrm{U}(\mathrm{VI})$ and $\mathrm{Tc}(\mathrm{VII}),{ }^{21-23}$ suggesting the potential of this bacterium in the biotransformation of heavy metals and biosynthesis of metal nanoparticles. ${ }^{24,25}$ Recently, the synthesis of silver nanoparticles and biotemplating of the preformed AuNPs into ordered arrays using S-layer protein lattices by $D$. radiodurans were investigated. ${ }^{26,27}$ However, there are no reports available on the efficiency and reduction mechanism of direct AuNPs biosynthesis by D. radiodurans or evaluation of the bioactive functions of the AuNPs. Moreover, AuNPs have significant potential in biomedical applications due to their biocompatibility and chemical inertness to mammalian cells, ${ }^{5-7}$ compared with the relatively toxic silver nanoparticles, which can induce argyrism. ${ }^{28}$ Based on previous studies on the resistance of $D$. radiodurans, we hypothesized that the extreme bacterium $D$. radiodurans may synthesize AuNPs efficiently due to its abundant supply of reductants.

In the present study, the ability of $D$. radiodurans to biosynthesize AuNPs in aqueous solution was determined. The AuNPs synthesized by $D$. radiodurans were characterized in detail by ultraviolet and visible (UV/Vis) spectroscopy, electron microscopy, energy-dispersive X-ray spectroscopy (EDX), X-ray diffraction (XRD), dynamic light scattering (DLS) and Fourier-transform infrared spectroscopy (FTIR). The mechanism of Au speciation and reduction by the bacterium was analyzed by X-ray photoelectron spectroscopy (XPS). The antibacterial activity of AuNPs as shown by cytomembrane damage in the Gram-positive bacterium (Staphylococcus aureus) and Gram-negative bacterium (E. coli) was evaluated to determine the biomedical potential of the AuNPs.

\section{Materials and methods}

\section{Bacterial cultures and chemicals}

D. radiodurans $\mathrm{R} 1$ (ATCC13939) was grown aerobically at $32^{\circ} \mathrm{C}$ in tryptone glucose yeast (TGY) broth $(0.5 \%$ tryptone, $0.1 \%$ glucose, $0.3 \%$ yeast extract) with agitation at $220 \mathrm{rpm}$. E. coli and $S$. aureus were grown at $37^{\circ} \mathrm{C}$ in Luria-Bertani (LB) medium $(1 \% \mathrm{NaCl}, 0.5 \%$ yeast extract and 1\% tryptone). Bacterial growth was assessed by measuring optical density $(\mathrm{OD})$ at $600 \mathrm{~nm}$ for $D$. radiodurans and $E$. coli and OD at $590 \mathrm{~nm}$ for $S$. aureus. Tetrachloroauric acid $\left(\mathrm{HAuCl}_{4} \cdot 3 \mathrm{H}_{2} \mathrm{O}\right)$ was purchased from Sigma Aldrich Co. (St Louis, MO, USA). All reagents used were of analytical grade. A gold(III) stock solution was obtained by dissolving $\mathrm{HAuCl}_{4}$ in ultrapure water. The gold(III) solutions used in this study were prepared by dilution of a $10 \mathrm{mM} \mathrm{HAuCl}_{4}$ stock solution. The $\mathrm{pH}$ of each working solution was adjusted by hydrochloric acid or sodium hydroxide. Chloramphenicol was used as a control in the antibacterial assays.

\section{Identification and dynamic analysis of AuNPs formation}

D. radiodurans $\mathrm{R} 1$ was incubated in TGY broth at $32^{\circ} \mathrm{C}$ until $\mathrm{OD}_{600 \mathrm{~nm}}$ reached 1.0. Then, $5 \mathrm{~mL}$ of the culture was centrifuged at $8,000 \times g$ for $10 \mathrm{~min}$. The obtained cell pellet was resuspended in $5 \mathrm{~mL}$ TGY broth added with $1 \mathrm{mM} \mathrm{Au(III).}$ The formation of AuNPs in the suspension was monitored by the color changes of the reaction mixtures, and the absorption spectrum of the suspension was measured at regular intervals 
by UV/Vis absorption spectroscopy (SpectraMax M5; Molecular Devices, Sunnyvale, CA, USA). The absorption spectra of sample aliquots from 480 to $620 \mathrm{~nm}$ were recorded as a function of reaction time. Appropriate controls including $\mathrm{Au}(\mathrm{III})$ solution plus TGY medium and D. radiodurans in TGY medium without $\mathrm{Au}(\mathrm{III})$ were measured at the same time for comparison.

The production of AuNPs was optimized by varying the reaction conditions including initial concentrations of $\mathrm{Au}(\mathrm{III})$ $(1,2.5$ and $5 \mathrm{mM})$, bacterial growth period $\left(\mathrm{OD}_{600 \mathrm{~nm}}=0.2,0.6\right.$, $0.8,1.0), \mathrm{pH}$ values $(2.5,4,7$ and 8.5$)$ and reaction temperatures $\left(25^{\circ} \mathrm{C}, 32^{\circ} \mathrm{C}\right.$ and $\left.37^{\circ} \mathrm{C}\right)$. The reaction time was $8 \mathrm{~h}$. The experiments were performed independently in triplicate.

\section{Preparation of AuNPs using $D$. radiodurans cells}

Cell pellets ( $250 \mathrm{mg}$, wet weight) of $D$. radiodurans obtained from cell culture as described were washed three times with deionized water, followed by incubation with $1 \mathrm{mM} \mathrm{Au(III)}$ solution at $32^{\circ} \mathrm{C}$ and $\mathrm{pH} 7.0$ for $8 \mathrm{~h}$. The resulting purplecolored solution was centrifuged at $8,000 \times g$ for $10 \mathrm{~min}$ to separate and collect the cell pellet and supernatant, respectively. The cell pellet was washed with deionized water until the supernatant was colorless. The supernatants were combined, filtered using $0.22 \mu \mathrm{m}$ syringe filters and then dialyzed against ultrapure water for $48 \mathrm{~h}$ with agitation. The bacterial pellets and dialyzed supernatant were frozen at $-20^{\circ} \mathrm{C}$ for $12 \mathrm{~h}$, respectively, and then transferred to $-80^{\circ} \mathrm{C}$ for $12 \mathrm{~h}$ and freeze-dried. The purified purple powders from the supernatant were used to characterize the AuNPs synthesized by $D$. radiodurans.

\section{Characterization of AuNPs}

The morphology, size and distribution of AuNPs within cells and the prepared AuNPs were characterized using transmission electron microscopy (TEM) and scanning electron microscopy (SEM). For TEM analysis, cells were suspended in $1 \mathrm{mM}$ gold ion solutions for $2 \mathrm{~h}$ and then centrifuged to collect the cells. The cells were fixed with $2.5 \%$ glutaraldehyde in phosphate buffer ( $\mathrm{pH} 7.0)$ overnight and then embedded in 5\% agar. The cells were dehydrated in a graded series of ethanol $(30 \%, 50 \%, 70 \%, 80 \%, 90 \%, 95 \%$ and $100 \%)$ for $15 \mathrm{~min}$ at each step and transferred to absolute acetone for $20 \mathrm{~min}$. Blocks were placed in a 1:1 (v/v) mixture of absolute acetone and the final Spurr resin mixture for $1 \mathrm{~h}$ at room temperature, and then transferred to a 1:3 (v/v) mixture of absolute acetone and the final resin mixture for $3 \mathrm{~h}$. The blocks were transferred to capsules containing embedding medium and heated at $70^{\circ} \mathrm{C}$ for $9 \mathrm{~h}$. The specimen was sectioned in LEICA EM UC7 ultratome, and sections were stained with uranyl acetate and lead citrate for 5-10 min, respectively, and observed using TEM (Hitachi Model H-7650; Hitachi, Tokyo, Japan). For SEM analysis, the samples were fixed and dehydrated as described, with the exception of the agarembedding step. The dehydrated sample was coated with palladium in Hitachi Model E-1010 ion sputter for 4-5 min and observed using a scanning electron microscope (Hitachi Model SU8010). Elemental composition of Au in the samples was analyzed by SEM-energy dispersive X-ray analysis (EDXA) (SU8010; Hitachi). EDXA spectrum was recorded in the area scan mode by focusing the electron beam onto a region of the sample surface.

The XRD pattern of prepared AuNPs from the supernatant after dialysis and lyophilization was measured using the X-ray diffractometer (X'Pert PRO; PANalytical Ltd., Almelo, the Netherlands) with $\mathrm{Cu} \mathrm{K} \alpha 1$ radiation with $\lambda=1.540 \AA$. Scanning was performed in the region of the $2 \theta$ angle from $20^{\circ}$ to $90^{\circ}$ with a step of $0.02^{\circ}$ and a 2 -second time constant for each step. ${ }^{29}$

Size distribution and surface charge of the AuNPs were measured by DLS and zeta potential analysis using a laser Doppler anemometer (Zetasizer Nano ZS; Malvern Instruments, Malvern, UK) at a wavelength of $632.8 \mathrm{~nm}$ using a $\mathrm{He}-\mathrm{Ne}$ laser beam at $25^{\circ} \mathrm{C}$. Briefly, $100 \mu \mathrm{L}$ of nanoparticles solution was diluted to $1 \mathrm{~mL}$ with deionized water. An electric field of $150 \mathrm{mV}$ was applied to observe the electrophoretic velocity of the particles. ${ }^{30}$

For FTIR analysis, the cell pellets with AuNPs were dried by lyophilization after dialysis against ultrapure water. Dried samples were crushed with $\mathrm{KBr}$ in a mortar at a ratio of 1:100. The pressed pellet was recovered with a clip and immediately analyzed in the region of 4,000-400 $\mathrm{cm}^{-1}$ at a resolution of approximately $2 \mathrm{~cm}^{-1}$ over 1,800 scans using Nicolet5700 FTIR spectrometer (Thermo Nicolet Co., Madison, WI, USA).

The prepared nanoparticles from the supernatant were mounted on a stainless steel holder, and the XPS analysis was performed using a high-performance X-ray photoelectron spectrometer (Escalab 250Xi; Thermo Scientific Co., Waltham, MA, USA) with monochromatic Al K $\alpha$ radiation of energy $1,486.6 \mathrm{eV}$. The peaks were assigned following standard procedures as described previously. ${ }^{10}$

\section{Antibacterial assays of AuNPs}

To assess the antibacterial potential of AuNPs, two pathogenic bacteria (Gram-positive $S$. aureus and Gram-negative 
E. coli) were selected. ${ }^{27}$ Antibacterial activities of the synthesized AuNPs were assessed using the standard dilution micromethod and agar diffusion test..$^{25,27,31}$ For the standard dilution micromethod, $1 \mathrm{~mL}$ bacterial culture was exposed to 100 and $150 \mu \mathrm{g} / \mathrm{mL}$ of AuNPs, respectively. Phosphatebuffered saline replaced AuNPs in the control. All the mixtures were incubated for $2 \mathrm{~h}$ at $37^{\circ} \mathrm{C}$ with continuous shaking (220 rpm). Bacterial survival was monitored by plating the culture on LB agar plates and counting the colonies.

The antibacterial activity and mobilization of AuNPs were also analyzed using the agar diffusion test. ${ }^{30}$ One hundred microliters of the suspended culture was uniformly spread on LB agar plates, and then, disks with a diameter of $6 \mathrm{~mm}$ containing $4 \mu \mathrm{L}$ of AuNPs $(20 \mathrm{mg} / \mathrm{mL})$ were gently placed in the center of the plates. The disk containing $2 \mu \mathrm{L}$ of $3 \mathrm{mg} / \mathrm{mL}$ chloramphenicol was used as a positive control. The plates were incubated at $37^{\circ} \mathrm{C}$ for $24 \mathrm{~h}$. The antibacterial activity was evaluated by measuring the diameter of the zone of inhibition. All experiments were conducted independently in triplicate.

The effects of AuNPs on the morphology and integrity of $S$. aureus and E. coli were observed using SEM. Bacterial cells were incubated with $100 \mu \mathrm{g} / \mathrm{mL}$ nanoparticles for $30 \mathrm{~min}$, and morphological changes were monitored by SEM as described.

\section{Statistical analysis}

The data were processed using Origin Pro version 8.0 (OriginLab Corporation, Northampton, MA, USA) and expressed as mean \pm standard deviation. Student's $t$-test was used to assess the significance of differences between results, and $P<0.05$ was considered significant.

\section{Results and discussion Biosynthesis of AuNPs by D. radiodurans}

In general, AuNPs in solution exhibit a purple to dark purple color with characteristic absorption in the range of $520-560 \mathrm{~nm}$, which is dependent on the morphology and size of the AuNPs. ${ }^{32,33}$ The color of the reaction mixture containing $D$. radiodurans and $1 \mathrm{mM} \mathrm{Au}(\mathrm{III})$ changed gradually from light red $(0 \mathrm{~min})$ to pale yellow $(10 \mathrm{~min})$, brown $(2 \mathrm{~h})$, light purple $(4 \mathrm{~h})$ and dark purple $(8 \mathrm{~h})$, visually indicating the formation of AuNPs in aqueous solution (Figure 1A). These colors were due to the excitation of surface plasmon vibrations, ${ }^{34}$ which is an intrinsic property of AuNPs and is used to indicate the formation of AuNPs. ${ }^{35}$ A characteristic peak of AuNPs was observed in D. radiodurans cultured with $1 \mathrm{mM}$ Au(III) (Figure 1B). The broadened absorption of AuNPs might be due to the fact that the generated nanoparticles adsorbed the biomolecules on the surface resulting in a wide resonance peak. ${ }^{36}$ No characteristic absorption of AuNPs was observed in the D. radiodurans culture alone or the TGY medium plus gold chloride, indicating that the AuNPs were formed by D. radiodurans cells. The $D$. radiodurans cell pellets could direct the formation of AuNPs (Figure S1) and were used for the preparation of AuNPs in the following experiments.

The time course of AuNPs formation at $\mathrm{pH} 7$ and $32^{\circ} \mathrm{C}$ was recorded by monitoring the characteristic peak of AuNPs at around $540 \mathrm{~nm}$ (Figure 1C). The absorbance of AuNPs increased with reaction time from 2 to $6 \mathrm{~h}$, corresponding to the color changes in the reaction mixtures (Figure 1A). The absorbance of AuNPs reached a maximum at $8 \mathrm{~h}$ and then remained unchanged, indicating that the relative production of AuNPs was maximum at that time and the reaction equilibrium had occurred. In general, the AuNPs biosynthetic process by bacteria achieves equilibrium by $16-120$ h. ${ }^{37,38}$ The present study and available literature (Table $\mathrm{S} 1$ ) show that D. radiodurans reacted with gold ions more rapidly compared with other bacteria, suggesting that $D$. radiodurans has an efficient ability to biosynthesize AuNPs. The color and absorption property of the AuNPs were maintained even after 3 months at room temperature (data not shown), indicating that the synthesized AuNPs were stable. Cellular antioxidants are involved in the transformation or detoxification of heavy metals. ${ }^{39} \mathrm{D}$. radiodurans cells have an expanded repertoire of antioxidants to protect against oxidative damage to nucleic acid and proteins, ${ }^{18,22,24}$ which might provide a reducing microenvironment to facilitate $\mathrm{Au}(\mathrm{III})$ reduction and AuNPs formation.

\section{Characterization of AuNPs from D. radiodurans}

The morphology, size and distribution of the synthesized AuNPs were analyzed by SEM and TEM. SEM images showed that AuNPs were accumulated as bright particles on the surface of D. radiodurans cells in 1 or $5 \mathrm{mM} \mathrm{Au}$ (III) (Figure 2A and B); this was confirmed by EDXA of the cell surface of $D$. radiodurans (Figure $2 \mathrm{C}$ ), which revealed the presence of characteristic peaks for Au along with trace peaks for $\mathrm{C}, \mathrm{N}, \mathrm{O}, \mathrm{P}$ and $\mathrm{S}$. The intensive Au peak at around $2.20 \mathrm{keV}$ due to the characteristic surface plasmon resonance of AuNPs corresponded with the formation of AuNPs. ${ }^{35,38,40}$ The peaks for $\mathrm{C}, \mathrm{N}, \mathrm{O}, \mathrm{P}$ and $\mathrm{S}$ might have arisen due to cellular components including proteins and carbohydrates, 


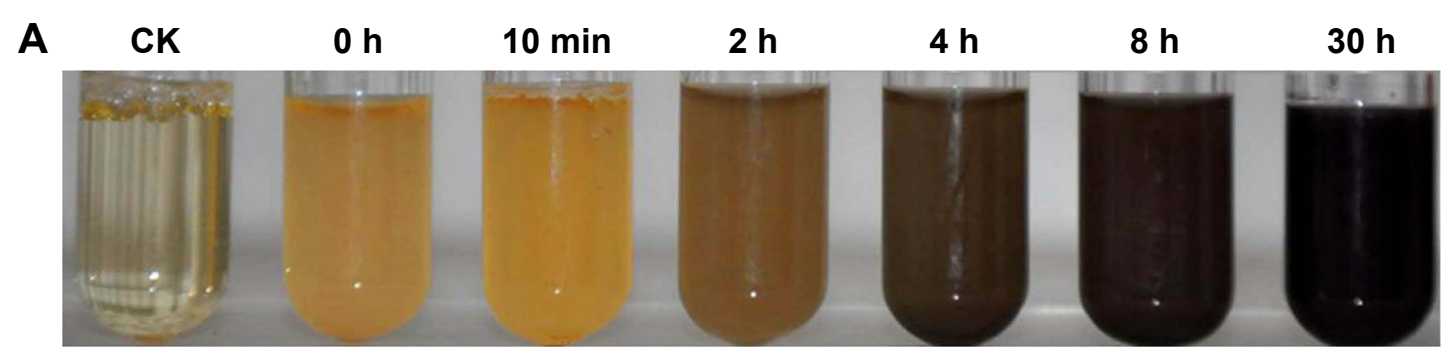

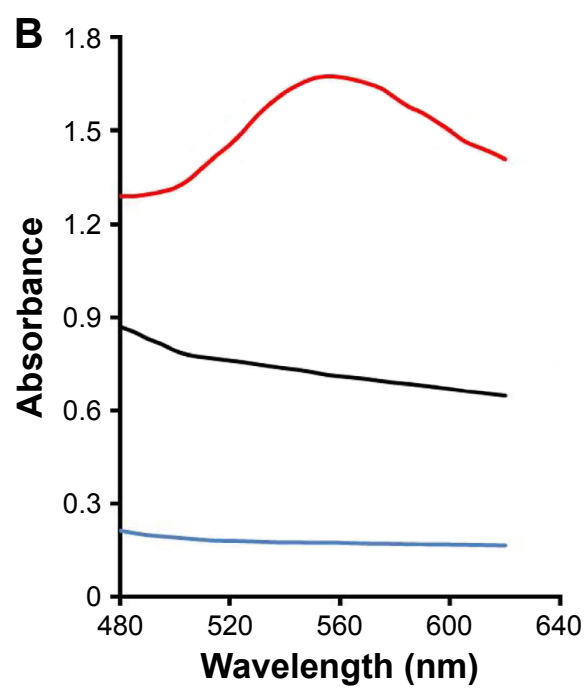

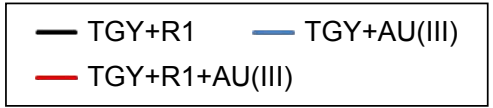

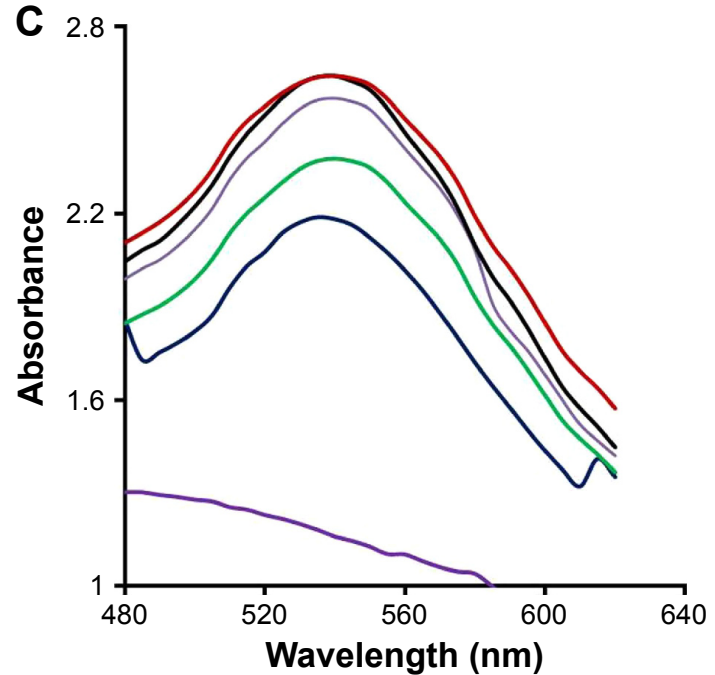

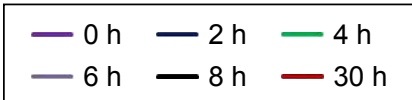

Figure I Identification and time course analysis of AuNPs biosynthesis by Deinococcus radiodurans.

Notes: (A) Change in the color of the solution containing D. radiodurans cultured in TGY medium and I mM Au(III) with respect to incubation time ( 0 and I0 min, and $2,4,8$ and $30 \mathrm{~h}$ ) compared to that without D. radiodurans (control, CK). (B) The absorbance spectra from 480 to $620 \mathrm{~nm}$ of AuNPs synthesized by D. radiodurans. Appropriate controls including $\mathrm{Au}$ (III) solution plus TGY medium (TGY+AU(III)) and D. radiodurans in TGY medium without Au(III) (TGY+RI) were measured at the same time for comparison. (C) The absorbance spectra of AuNPs formation with respect to the incubation time. The characteristic peak of AuNPs was visualized at approximately $540 \mathrm{~nm}$.

Abbreviations: AuNPs, gold nanoparticles; D. radiodurans, Deinococcus radiodurans; h, hours: TGY, tryptone glucose yeast.

which might have acted as stabilizing or capping agents in the formation of AuNPs. In the SEM images, the AuNPs were of spherical, pseudo-spherical, truncated triangular and irregular shapes which were observed on the cell surface (Figure 2A and B) and were more evident in the image of the prepared AuNPs from the cell supernatant (Figure 2D).

The TEM microgram showed that AuNPs were distributed on the cell envelope, across the cytosol as well as in the extracellular space (Figure 2E). The presence of intracellular AuNPs suggests that gold ions can be transported into the cells and reduced to AuNPs.

To characterize the crystallite nature of AuNPs, XRD analysis of lyophilized AuNPs was conducted. The face-centered cubic structure of atomic gold crystals was represented by the intense diffraction peaks from the AuNPs (Figure 3A), confirming the crystalline nature of the AuNPs. The peaks appeared at $38.27^{\circ}, 44.37^{\circ}, 64.54^{\circ}, 77.80^{\circ}$ and $81.74^{\circ}$ in the
$2 \theta$ range of $20^{\circ}-90^{\circ}$, corresponding to the characteristic diffractions of the (111), (200), (220), (311) and (222) planes of the face-centered cubic Au structure, respectively. The intensity ratios of the (200)/(111) and (220)/(111) peaks of AuNPs were approximately 0.55 and 0.37 , consistent with the standard intensity ratios $(0.52$ and 0.33$) .{ }^{41}$ The (111) lattice plane was the main crystal orientation of the AuNPs. Considering the (111) peak, the average crystallite size was estimated using the Debye-Scherrer equation $(D=0.89 \lambda / \beta \operatorname{Cos} \theta)$, where $D$ is the average crystallite domain size perpendicular to the reflecting planes, $\lambda$ is the wavelength of the X-ray source $(0.1541 \mathrm{~nm}), \beta$ is the full width at half-maximum (FWHM) of the (111) peak in radians and $\theta$ is the diffraction angle..$^{27,42}$ The FWHM value was corrected using that of a large-grained $\mathrm{Si}$ and $\beta_{\text {corrected }}=\left(\mathrm{FWHM}_{\text {sample }}{ }^{2}-\mathrm{FWHM}_{\mathrm{si}}{ }^{2}\right)^{1 / 2} \cdot{ }^{42}$ The size of the AuNPs was estimated by this equation to be approximately $36.28 \mathrm{~nm}$. 


\section{A}

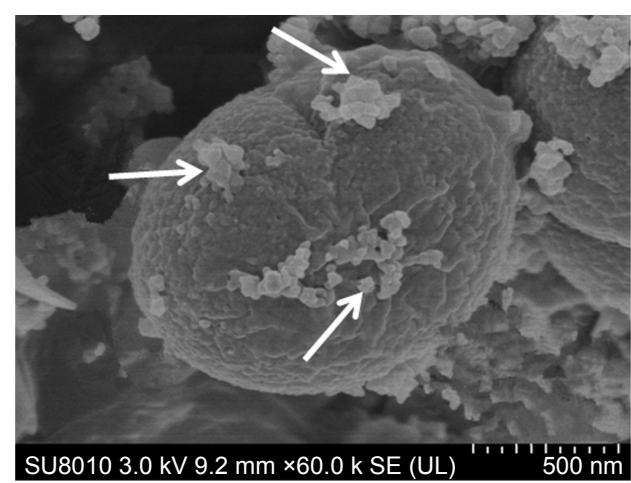

B

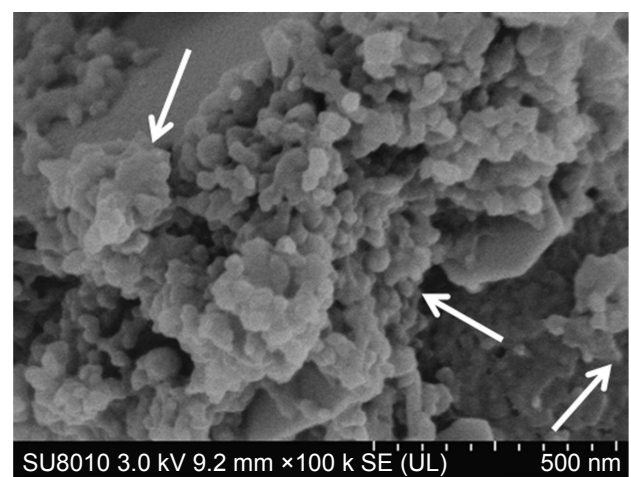

C

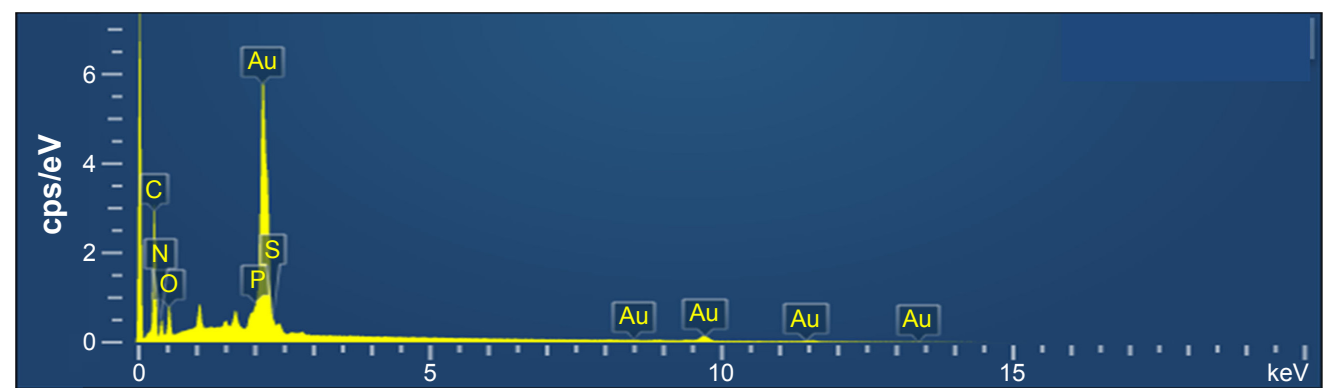

D

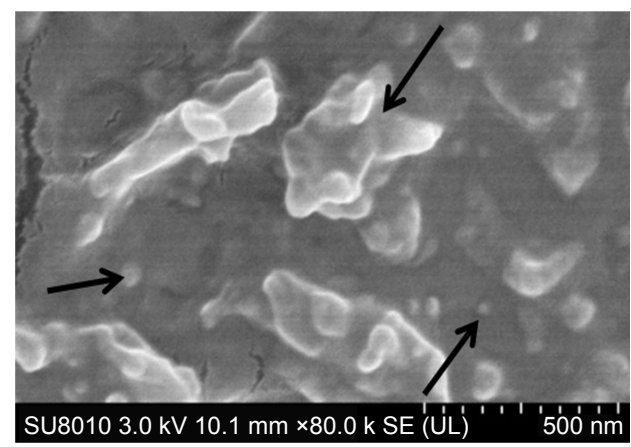

$\mathbf{E}$

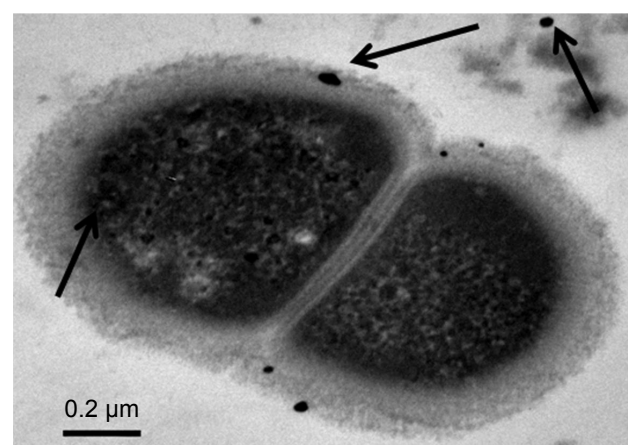

Figure 2 SEM-EDXA and TEM analysis of AuNPs synthesized by Deinococcus radiodurans.

Notes: (A and B) SEM images of AuNPs-loaded D. radiodurans cells with I mM Au(III) and $5 \mathrm{mM} \mathrm{Au(III),} \mathrm{respectively.} \mathrm{(C)} \mathrm{EDX} \mathrm{spectra} \mathrm{of} \mathrm{AuNPs-loaded} \mathrm{D.} \mathrm{radiodurans} \mathrm{cells.}$ (D) SEM image of purified AuNPs synthesized by D. radiodurans with I mM Au(III). (E) TEM image of AuNPs-loaded D. radiodurans cells. Arrows in A and B indicate the AuNPs on cell surface. Arrows in $\mathbf{D}$ indicate different morphologies and sizes of the purified AuNPs. Arrows in $\mathbf{E}$ indicate the AuNPs distributed on the cell envelope, across the cytosol as well as in the extracellular space. Scale bars in the pictures indicate the corresponding length.

Abbreviations: SEM, scanning electron microscopy; EDXA, energy-dispersive X-ray analysis; TEM, transmission electron microscopy; AuNPs, gold nanoparticles; EDX, energy-dispersive spectroscopy; $D$. radiodurans, Deinococcus radiodurans.
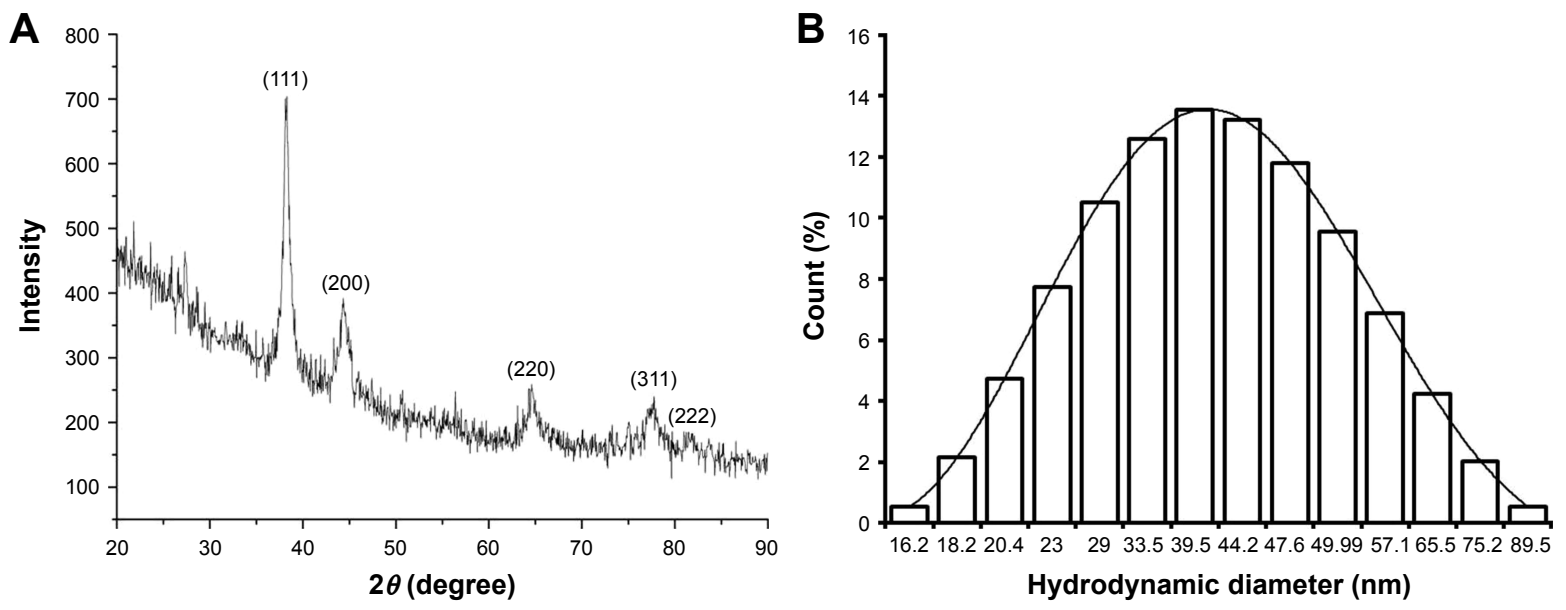

Figure 3 XRD and DLS analyses of AuNPs.

Notes: (A) XRD pattern of the purified AuNPs. The Braggs reflections were identified in the XRD. (B) The distribution of hydrodynamic diameter of AuNPs measured by DLS. Abbreviations: XRD, X-ray diffraction; DLS, dynamic light scattering; AuNPs, gold nanoparticles. 
The hydrodynamic particle size and zeta potential of AuNPs were further measured using the Zetasizer Nano ZS. As shown in Figure 3B, the formed AuNPs were highly monodispersed, and the average size of the AuNPs was $43.75 \mathrm{~nm}$ while the size of the highest percentage of AuNPs $(13.55 \%)$ was $39.5 \mathrm{~nm}$, which matched with the size of nanoparticles observed by SEM and TEM and estimated by XRD. The observed difference in AuNPs' size may be due to the effects of biomolecules acting as a capping agent and forming a covering on the nanoparticles. ${ }^{43}$ The zeta potential value $(-20.01 \pm 0.17 \mathrm{mV})$ with the polydispersity index $(0.23 \pm 0.002$ at $\mathrm{pH} 7)$ of AuNPs indicated that the AuNPs were stable. ${ }^{31,44}$

FTIR analysis was performed to determine the possible functional groups of biomolecules involved in the reduction of gold ions and stabilization of the synthesized AuNPs from D. radiodurans incubated with $\mathrm{Au}(\mathrm{III})$. The FTIR signals of D. radiodurans cell pellets in the absence of Au treatment showed obvious bands at 3,302, 2,930, 2,363, 1,655, 1,541, $1,452,1,400,1,242,1,073$ and $547 \mathrm{~cm}^{-1}$ (Figure 4A). The strong band at $3,302 \mathrm{~cm}^{-1}$ may be assigned to the stretching vibration of $\mathrm{OH}$ or $\mathrm{NH}$ groups present in carbohydrates or proteins. ${ }^{32}$ In the AuNPs-loaded D. radiodurans cells (Figure 4B), the $\mathrm{OH}$ or $\mathrm{NH}$ band at $3,302 \mathrm{~cm}^{-1}$ shifted to $3,404 \mathrm{~cm}^{-1}$, indicating that the $\mathrm{OH}-$ or $\mathrm{NH}$-containing carbohydrates or proteins might have been involved in the reduction and capping of $\mathrm{Au}$ ions to form AuNPs. ${ }^{32}$ D. radiodurans cells exhibited intense bands at 1,655 and $1,543 \mathrm{~cm}^{-1}$, which corresponded to the stretching peaks of amide I and II groups of polypeptides/proteins. Following the formation of AuNPs, the amide I and II bands shifted slightly to 1,650 and $1,539 \mathrm{~cm}^{-1}$, respectively. Moreover, the band at $1,452 \mathrm{~cm}^{-1}$ might be ascribed to the methylene scissoring vibration in proteins and shifted to $1,447 \mathrm{~cm}^{-1}$ during the formation of AuNPs. The bands at $1,073 \mathrm{~cm}^{-1}$ corresponding to $\mathrm{P}-\mathrm{O}-\mathrm{C}$ stretching vibrations shifted to $1,082 \mathrm{~cm}^{-1}$ in AuNPs-loaded D. radiodurans, indicating the interaction between phosphoprotein and the AuNPs surface. These results were consistent with the $\mathrm{C}, \mathrm{N}, \mathrm{O}$ and $\mathrm{P}$ peaks in the area profile of EDX for AuNPs-loaded D. radiodurans (Figure 2C). It was reported that AuNPs can interact with proteins through free amine groups or cysteine residues via
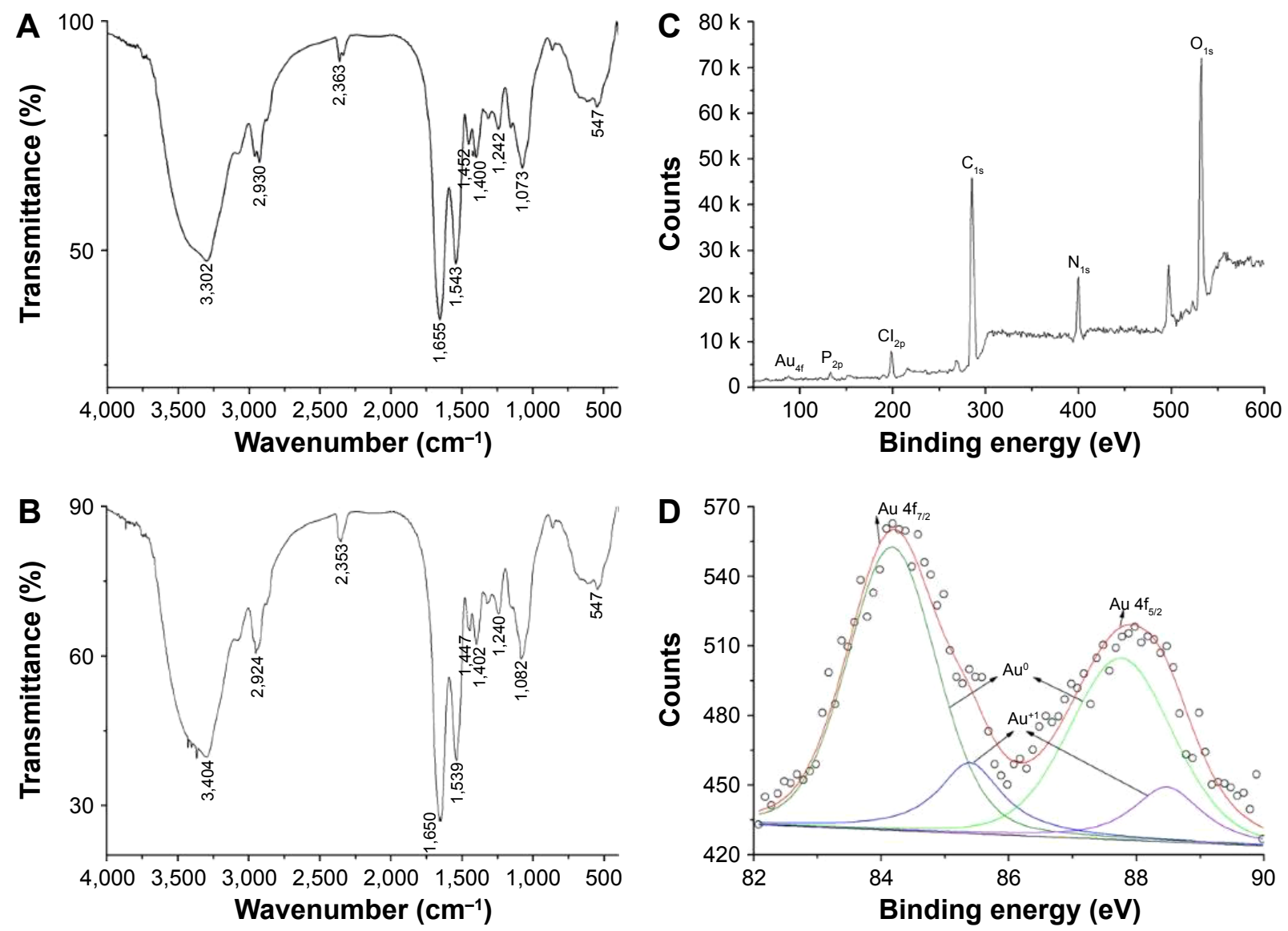

Figure 4 FTIR and XPS analyses of AuNPs synthesis.

Notes: FTIR spectra of Deinococcus radiodurans (A) before and (B) after interaction with I mM Au(III). (C) XPS spectra of prepared AuNPs and (D) the core level of Au(4f), $\mathrm{Au}(0)$ and $\mathrm{Au}(\mathrm{I})$ peaks.

Abbreviations: FTIR, Fourier transform infrared spectroscopy; XPS, X-ray photoelectron spectroscopy; AuNPs, gold nanoparticles. 
electrostatic attraction of negatively charged carboxyl or carbonyl groups, to form a coating on the nanoparticles to prevent agglomeration, thus leading to stabilization of the AuNPs. ${ }^{45} \mathrm{OH}$ and $\mathrm{NH}_{2}$ groups on the cell surface of Pichia pastoris and the carbonyl group in protein extract of Rhizopus oryzae were shown to be involved in the reduction of gold ions and the formation of AuNPs. ${ }^{38,46}$ Therefore, the shifting bands of different functional groups in the AuNPs obtained from D. radiodurans demonstrated that hydroxyl, amine and phospho groups might play important roles in the reduction and stabilization of the synthesized AuNPs. D. radiodurans contains numerous antioxidant compounds including carotenoid, pyrroloquinoline-quinone and phosphoproteins, which are rich in hydroxyl, phospho or amine groups. Some unique proteins were also identified in D. radiodurans, such as PprI, ${ }^{47}$ which are involved in regulation of cellular antioxidant system and stress response. ${ }^{18,48}$ These compounds and proteins might have been responsible for the reduction and stabilization of the synthesized AuNPs in this bacterium.

The speciation of $\mathrm{Au}$ in the reduction process was studied using the XPS technique. The peaks for $\mathrm{C}_{1 \mathrm{~s}}, \mathrm{~N}_{1 \mathrm{~s}}, \mathrm{O}_{1 \mathrm{~s}}, \mathrm{P}_{2 \mathrm{p}}$, $\mathrm{Cl}_{2 \mathrm{p}}$ and $\mathrm{Au}_{4 \mathrm{f}}$ were observed in AuNPs from the dialyzed and lyophilized supernatant (Figure 4C), consistent with a previous report. ${ }^{29}$ The peak of $\mathrm{C}_{1 \mathrm{~s}}$ at $284.8 \mathrm{eV}$ was used as the charge reference to determine core-level binding energies (Figure $\mathrm{S} 2$ ). The core-level spectra of $\mathrm{C}_{1 \mathrm{~s}}, \mathrm{~N}_{1 \mathrm{~s}}, \mathrm{O}_{1 \mathrm{~s}}$ and $\mathrm{P}_{2 \mathrm{p}}$ provided more evidence that cell functional groups, for example, carboxyl, amine, hydroxyl and phosphate, might provide reducing and capping sites for AuNPs formation, consistent with the results of the FTIR assay. The Au $4 \mathrm{f}$ spectrum composed of doublet peaks corresponding to $\mathrm{Au}$ $4 \mathrm{f}_{7 / 2}$ and $\mathrm{Au} 4 \mathrm{f}_{5 / 2}$ at 83.8 and $87.5 \mathrm{eV}$, respectively, could be assigned to $\mathrm{Au}(0)$ (Figure 4D). In addition, the asymmetry in peaks might be assigned to $\mathrm{Au}(\mathrm{I})$, corresponding to an additional chemical state of $\mathrm{Au}$ during the reduction of $\mathrm{Au}$ ions. ${ }^{29,49}$ Therefore, a small amount of $\mathrm{Au}(\mathrm{I})$ remained on the coated AuNPs surface, indicating that the AuNPs were formed through intermediate $\mathrm{Au}(\mathrm{I})$ species. The XPS results demonstrated that upon binding to the reducing and capping sites, $\mathrm{Au}(\mathrm{III})$ might firstly be reduced to $\mathrm{Au}(\mathrm{I})$ species, and then further reduced to $\mathrm{Au}(0)$, and AuNPs formation was achieved with the capping factors. The reduction mechanism of $D$. radiodurans on noble metals has not been reported in previous studies. ${ }^{25,26}$ The properties of AuNPs strongly depend on interactions between the nanoparticles and the adsorbed species on the surface of nanoparticles. ${ }^{35}$ The reducing and capping factors for AuNPs present in D. radiodurans are still not fully known; however, we propose that the antioxidant compounds and related proteins in this bacterium may have provided reducing and stabilizing agents to convert $\mathrm{Au}(\mathrm{III})$ via $\mathrm{Au}(\mathrm{I})$ into AuNPs.

\section{Effects of reaction conditions on AuNPs biosynthesis}

The effects of initial concentrations of gold salt, growth period (cell density) of bacterium, solution $\mathrm{pH}$ and reaction temperature on AuNPs biosynthesis were investigated by measuring the absorption spectra of AuNPs as the intensity of absorption is proportional to the production of AuNPs and the wavelength of maximum absorption is related to the size of AuNPs. ${ }^{35,44,50,51}$ As shown in Figure 5, different concentrations of $\mathrm{Au}(\mathrm{III})$ aqueous solution, $\mathrm{pH}$, bacterial growth period and reaction temperatures had a marked effect on the formation of AuNPs. The relative intensity of absorption increased with an increase of initial concentration of gold ions or bacterial density (Figure 5A and B), indicating that the production of AuNPs was higher in the presence of enhanced supplement of metal ion substrate or bacterial cells. Figure 5C shows that $D$. radiodurans showed higher production of AuNPs at acidic $\mathrm{pH}(2.5-4)$ than that at the other tested $\mathrm{pH}$ and the maximum production was found at $\mathrm{pH} 4$. $\mathrm{pH}$ is an important factor which affects the interaction between biosorbents and metal ions due to which it can influence the chemical environment of biosorbents (eg, protonation) as well as the properties of metal ions. At lower $\mathrm{pH}$, the cell ligands were protonated to a higher degree, resulting in an overall more positive surface charge, which increased the electrostatically driven passive sorption of the negatively charged $\mathrm{Au}$ (III) complex onto the cells. ${ }^{33}$ However, the biosynthesis capacity at $\mathrm{pH} 2.5$ was lower than that at $\mathrm{pH} 4$, probably due to competition of protonation at the functional binding sites of bacterial cells on $\mathrm{Au}$ (III). It was also observed that the characteristic absorption of AuNPs was blue shifted when $\mathrm{pH}$ was increased (7-8.5), which was attributed to a decrease in particle size with the change in $\mathrm{pH} .{ }^{50}$ Figure $5 \mathrm{D}$ shows the effects of temperature $\left(25^{\circ} \mathrm{C}, 32^{\circ} \mathrm{C}\right.$ and $\left.37^{\circ} \mathrm{C}\right)$ on the formation of AuNPs by D. radiodurans. Relatively high AuNPs production was demonstrated at $32^{\circ} \mathrm{C}$, which approached the optimum growth temperature for $D$. radiodurans.

\section{Antibacterial activity of AuNPs}

The antibacterial activity of the biosynthesized AuNPs was evaluated against $E$. coli and $S$. aureus using the standard dilution micromethod and disk diffusion assay. Figure 6A shows the colony forming units per mililiter of the two pathogens in the presence of different concentrations of AuNPs. Nanoparticles at $150 \mu \mathrm{g} / \mathrm{mL}$ inhibited $44.76 \%$ and $74.15 \%$ of $S$. aureus and $E$. coli, respectively, which was 

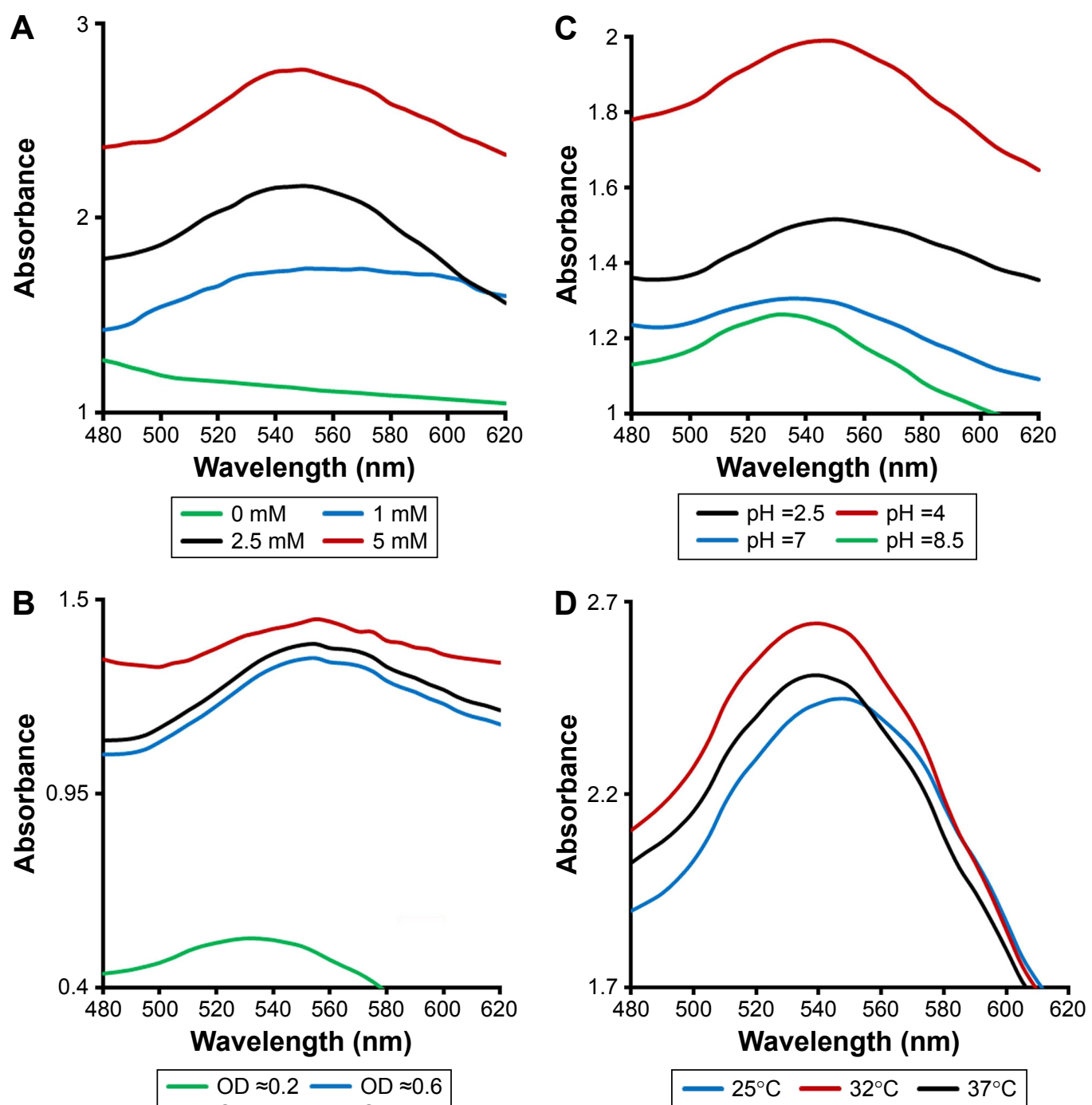

Figure 5 Effects of reaction conditions on AuNPs biosynthesis.

Notes: The absorption spectral analysis of AuNPs formation over the wavelength range of 480-620 nm after $8 \mathrm{~h}$ of reaction under different conditions: (A) initial concentration of $\mathrm{Au}(\mathrm{III})$, (B) cell density $\left(\mathrm{OD}_{600 \mathrm{~nm}}\right)$ of Deinococcus radiodurans, (C) initial $\mathrm{pH}$ and (D) incubation temperature.

Abbreviations: AuNPs, gold nanoparticles; OD, optical density.
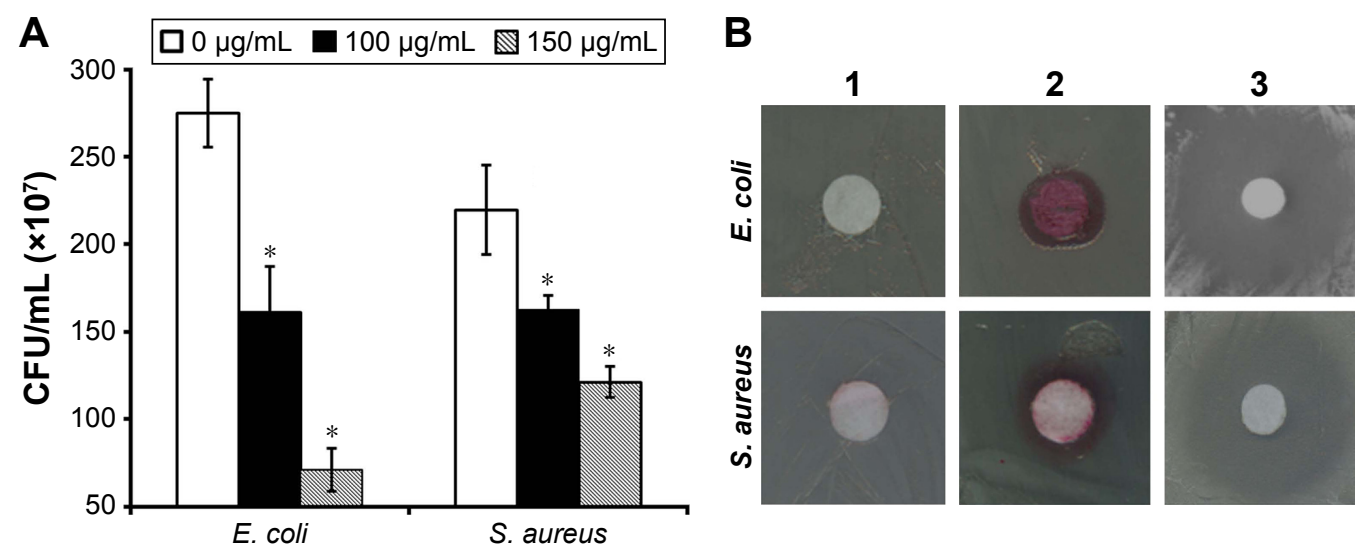

Figure 6 Antibacterial activity of AuNPs.

Notes: (A) The survival (CFU/mL) of Escherichia coli and Staphylococcus aureus in the presence of 100 and $150 \mu \mathrm{g} / \mathrm{mL}$ AuNPs. The asterisks indicate significance $(P<0.05)$ using Student's t-test. (B) Inhibition zones of (I) PBS buffer, (2) $80 \mu \mathrm{g} / \mathrm{disc}$ AuNPs and (3) $6 \mu \mathrm{g} / \mathrm{disc}$ chloramphenicol on E. coli and S. aureus. The experiments were conducted independently in triplicate, and a representative result of the reproducible experiments is shown.

Abbreviations: AuNPs, gold nanoparticles; CFU, colony forming units; PBS, phosphate-buffered saline; E. coli, Escherichia coli; S. aureus, Staphylococcus aureus. 

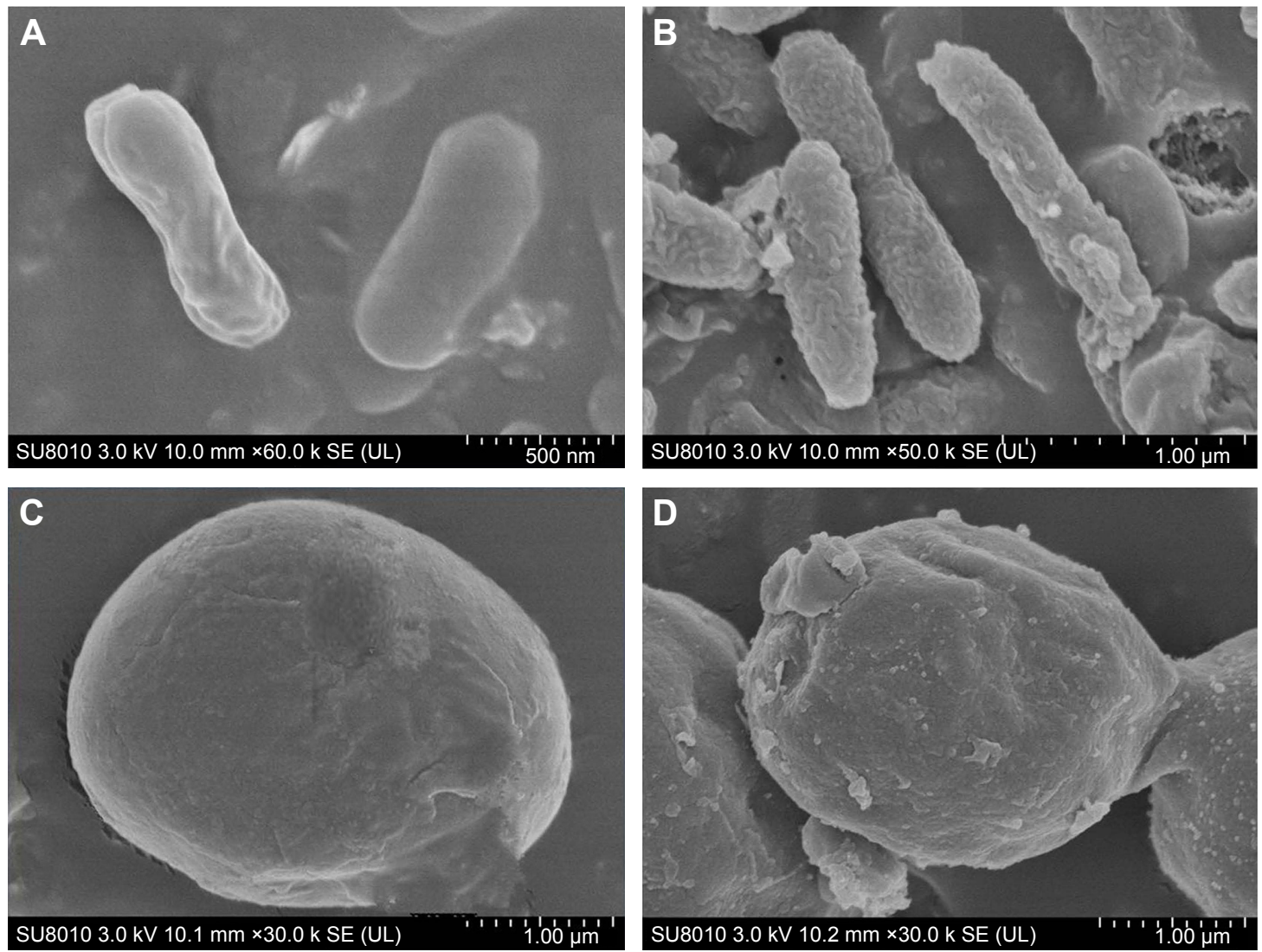

Figure 7 The morphological changes in Escherichia coli and Staphylococcus aureus following AuNPs treatment.

Notes: SEM images of (A and B) E. coli and (C and D) S. aureus (A and $\mathbf{C})$ before and (B and $\mathbf{D})$ after the treatment with $100 \mu \mathrm{g} / \mathrm{mL} \mathrm{AuNPs}$ for $30 \mathrm{~min}$. Scale bars are shown under the images.

Abbreviations: AuNPs, gold nanoparticles; SEM, scanning electron microscopy; E. coli, Escherichia coli; S. aureus, Staphylococcus aureus.

in agreement with previous findings where AuNPs acted as an antimicrobial agent. ${ }^{31}$ It was found that the inhibition by AuNPs was more significant for Gram-negative $E$. coli than Gram-positive S. aureus, which was attributed to the differences in their cell wall compositions and growth rates. ${ }^{25,52}$ The antibacterial property of AuNPs was also evaluated using the disk diffusion assay (Figure 6B). The average diameter of the inhibition zone of AuNPs at $80 \mu \mathrm{g} / \mathrm{disc}$ was $9.21 \pm 0.20 \mathrm{~mm}$ for Gram-negative E. coli and was $8.95 \pm 0.17 \mathrm{~mm}$ for Gram-positive $S$. aureus. Chloramphenicol at $6 \mu \mathrm{g} / \mathrm{disc}$ was used as a positive control.

SEM images demonstrated the morphological changes in $S$. aureus and E. coli before and after incubation with $100 \mu \mathrm{g} / \mathrm{mL}$ AuNPs for $30 \mathrm{~min}$. Untreated bacteria exhibited membrane structure integrity with a smooth surface (Figure 7A and C). In contrast, the surface of S. aureus and E. coli showed vesicles and damages following incubation with AuNPs (Figure 7B and D), indicating that AuNPs might attach and penetrate the cell membrane of bacteria resulting in disruption of the cytoplasmic membrane. The structural integrity and stability of the membrane as a permeability barrier was subsequently lost, leading to bacterial death..$^{27,53}$ Other antibacterial mechanisms of AuNPs have been proposed; for example, AuNPs may bind to DNA and inhibit the transcription of DNA in bacteria. ${ }^{52,54,55}$ However, the relatively inert AuNPs with appropriate coating are thought to have no side effects on human health. ${ }^{56-58}$ Moreover, the AuNPs used in the present study were obtained from the nonpathogenic bacterium D. radiodurans, and the antibacterial activities of these AuNPs have potential biomedical applications.

\section{Conclusion}

We describe a rapid and efficient method for the synthesis of AuNPs using D. radiodurans. To the best of our knowledge, this is the first study on the biosynthesis and characterization of AuNPs from the extreme bacterium D. radiodurans. Because D. radiodurans survives well in extreme environments such as oxidant stresses, compared with other bacteria, it is a promising candidate for the biosynthesis of AuNPs from radioactive or oxidant mixtures. The AuNPs formation process, which includes the interactions of $\mathrm{Au}$ (III) with hydroxyl, amine, phospho and carboxyl groups of 
proteins or compounds and reduction of $\mathrm{Au}(\mathrm{III})$ to $\mathrm{Au}(0)$ via the intermediate state of $\mathrm{Au}(\mathrm{I})$, was demonstrated. The production of AuNPs can be optimized by varying the concentrations of $\mathrm{Au}(\mathrm{III})$, bacterial cell density and reaction $\mathrm{pH}$ and temperatures. AuNPs obtained from the nonpathogenic D. radiodurans exhibited damaging effects on the cytoplasmic membrane of both Gram-positive and Gram-negative pathogenic bacteria, which highlights its potential in biomedical applications.

\section{Acknowledgments}

The authors thank Dr Yangfan Lu at the School of Materials Science and Engineering of Zhejiang University for the help in XPS analysis. This work was supported by grants from the National Natural Science Foundation of China (31370119, 31170079, 31210103904, 31370102), a major project for genetically modified organisms breeding from the Ministry of Agriculture of China (2013ZX08009003-002) and the Natural Science Foundation of Zhejiang Province (LY13C010001).

\section{Disclosure}

The authors report no conflicts of interest in this work.

\section{References}

1. Southam G, Saunders JA. Geomicrobiology in contemporary natural systems: implications for economic geology. Econ Geol. 2005;100: 1067-1084.

2. Ta C, Reith F, Brugger J, Pring A, Lenehan CE. Analysis of gold(I/III)complexes by HPLC-ICP-MS demonstrates gold(III) stability in surface waters. Environ Sci Technol. 2014;48(10):5737-5744.

3. Schmid G. Large clusters and colloids. Metals in the embryonic state. Chem Rev. 1992;92(8):1709-1727.

4. Daniel MC, Astruc D. Gold nanoparticles: assembly, supramolecular chemistry, quantum-size-related properties, and applications toward biology, catalysis, and nanotechnology. Chem Rev. 2004;104(1): 293-346.

5. Khalavka Y, Becker J, Sönnichsen C. Synthesis of rod-shaped gold nanorattles with improved plasmon sensitivity and catalytic activity. J Am Chem Soc. 2009;131(5):1871-1875.

6. Tiwari PM, Vig K, Dennis VA, Singh SR. Functionalized gold nanoparticles and their biomedical applications. Nanomaterials. 2011;1(1): 31-63.

7. Darbha GK, Ray A, Ray PC. Gold nanoparticle-based miniaturized nanomaterial surface energy transfer probe for rapid and ultrasensitive detection of mercury in soil, water, and fish. ACS Nano. 2007;1(3): 208-214.

8. Liu X, Wu N, Wunsch BH, Barsotti RJ Jr, Stellacci F. Shape-controlled growth of micrometer-sized gold crystals by a slow reduction method. Small. 2006;2(8-9):1046-1050.

9. Choi YJ, Chiu CK, Luo TJ. Spontaneous deposition of gold nanoparticle nanocomposite on polymer surfaces through sol-gel chemistry. Nanotechnology. 2011;22(4):045601.

10. Das SK, Liang J, Schmidt M, Laffir F, Marsili E. Biomineralization mechanism of gold by zygomycete fungi Rhizopous oryzae. ACS Nano. 2012;6(7):6165-6173.

11. Reith F, Rogers SL, Mcphail DC, Webb D. Biomineralization of gold: biofilms on bacterioform gold. Science. 2006;313(5784):233-236.
12. Thakkar KN, Mhatre SS, Parikh RY. Biological synthesis of metallic nanoparticles. Nanomedicine. 2010;6(2):257-262.

13. Du L, Jiang H, Liu X, Wang E. Biosynthesis of gold nanoparticles assisted by Escherichia coli $\mathrm{DH} 5 \alpha$ and its application on direct electrochemistry of hemoglobin. Electrochem Commun. 2007;9(5):1165-1170.

14. Srivastava SK, Yamada R, Ogino C, Kondo A. Biogenic synthesis and characterization of gold nanoparticles by Escherichia coli K12 and its heterogeneous catalysis in degradation of 4-nitrophenol. Nanoscale Res Lett. 2013;8(1):70.

15. Reith F, Lengke MF, Falconer D, Craw D, Southam G. The geomicrobiology of gold. ISME J. 2007;1(7):567-584.

16. Tiwari M, Krishnamurthy S, Shukla D, et al. Comparative transcriptome and proteome analysis to reveal the biosynthesis of gold nanoparticles in Arabidopsis. Sci Rep. 2016;6:21733.

17. Kikuchi T, Tanaka S. Biological removal and recovery of toxic heavy metals in water environment. Crit Rev Environ Sci Technol. 2012;42(10): 1007-1057.

18. Anderson AW, Nordon HC, Cain RF, Parrish G, Duggan D. Studies on a radioresistant micrococcus. I. Isolation, morphology, cultural characteristics, and resistance to gamma radiation. Food Technol. 1956;10(12): 575-578.

19. Slade D, Radman M. Oxidative stress resistance in Deinococcus radiodurans. Microbiol Mol Biol Rev. 2011;75(1):133-191.

20. Daly MJ, Gaidamakova EK, Matrosova VY, et al. Small-molecule antioxidant proteome-shields in Deinococcus radiodurans. PLoS One. 2009;5(9):e12570.

21. Kulkarni S, Ballal A, Apte SK. Bioprecipitation of uranium from alkaline waste solutions using recombinant Deinococcus radiodurans. J Hazard Mater. 2013;262:853-861.

22. Fredrickson JK, Kostandarithes HM, Li SW, Plymale AE, Daly MJ. Reduction of Fe(III), Cr(VI), U(VI), and Tc(VII) by Deinococcus radiodurans R1. Appl Environ Microbiol. 2000;66(5):2006-2011.

23. Brim H, McFarlan SC, Fredrickson JK, et al. Engineering Deinococcus radiodurans for metal remediation in radioactive mixed waste environments. Nat Biotechnol. 2000;18(1):85-90.

24. Daly MJ. Engineering radiation-resistant bacteria for environmental biotechnology. Curr Opin Biotechnol. 2000;11(3):280-285.

25. Misra CS, Appukuttan D, Kantamreddi VS, Rao AS, Apte SK. Recombinant $D$. radiodurans cells for bioremediation of heavy metals from acidic/neutral aqueous wastes. Bioeng Bugs. 2012;3(1):44-48.

26. Kulkarni RR, Shaiwale NS, Deobagkar DN, Deobagkar DD. Synthesis and extracellular accumulation of silver nanoparticles by employing radiation-resistant Deinococcus radiodurans, their characterization, and determination of bioactivity. Int J Nanomedicine. 2015;10:963-974.

27. Hall SR, Shenton W, Engelhardt H, Mann S. Site-specific organization of gold nanoparticles by biomolecular templating. Chemphyschem. 2001;2(3):184-186.

28. Mei L, Zhang X, Wang Y, et al. Multivalent polymer-Au nanocomposites with cationic surfaces displaying enhanced antimicrobial activity. Polym Chem. 2014;5(8):3038-3044.

29. Boulc'h FH, Schouler MC, Donnadieu P, Chaix JM, Djurado E. Domain size distribution of Y-TZP nano-particles using XRD and HRTEM. Image Anal Stereol. 2001;20:157-161.

30. Marslin G, Selvakesavan RK, Franklin G, Sarmento B, Dias AC. Antimicrobial activity of cream incorporated with silver nanoparticles biosynthesized from Withania somnifera. Int J Nanomedicine. 2015; 10:5955-5963.

31. Mishra A, Kumari M, Pandey S, Chaudhry V, Gupta KC, Nautiyal CS. Biocatalytic and antimicrobial activities of gold nanoparticles synthesized by Trichoderma sp. Bioresour Technol. 2014;166:235-242.

32. Pimprikar PS, Joshi SS, Kumar AR, Zinjarde SS, Kulkarni SK. Influence of biomass and gold salt concentration on nanoparticle synthesis by the tropical marine yeast Yarrowia lipolytica NCIM 3589. Colloids Surf B Biointerfaces. 2009;74(1):309-316.

33. Reith F, Etschmann B, Grosse C. Mechanisms of gold biomineralization in the bacterium Cupriavidus metallidurans. Proc Natl Acad Sci US A. 2009;106(42):17757-17762. 
34. Kalishwaralal K, Deepak V, Ram Kumar Pandian S, et al. Biosynthesis of silver and gold nanoparticles using Brevibacterium casei. Colloids Surf B Biointerfaces. 2010;77(2):257-262.

35. Das SK, Das AR, Guha AK. Microbial synthesis of multishaped gold nanostructures. Small. 2010;6(9):1012-1021.

36. Chen H, Shao L, Li Q, Wang J. Gold nanorods and their plasmonic properties. Chem Soc Rev. 2013;42(7):2679-2724.

37. Scott D, Toney M, Muzikár M. Harnessing the mechanism of glutathione reductase for synthesis of active site bound metallic nanoparticles and electrical connection to electrodes. J Am Chem Soc. 2008; 130(3):865-874.

38. Das SK, Dickinson C, Lafir F, Brougham DF, Marsili E. Synthesis, characterization and catalytic activity of gold nanoparticles biosynthesized with Rhizopus oryzae protein extract. Green Chem. 2012;14(5): $1322-1334$.

39. Checa SK, Soncini FC. Bacterial gold sensing and resistance. Biometals. 2011;24(3):419-427.

40. Elavazhagan T, Arunachalam KD. Memecylon edule leaf extract mediated green synthesis of silver and gold nanoparticles. Int J Nanomedicine. 2011;6:1265-1278.

41. Hwang SJ, Jun SH, Park Y, et al. Green synthesis of gold nanoparticles using chlorogenic acid and their enhanced performance for inflammation. Nanomedicine. 2015;11(7):1677-1688.

42. Arunachalam KD, Annamalai SK. Chrysopogon zizanioides aqueous extract mediated synthesis, characterization of crystalline silver and gold nanoparticles for biomedical applications. Int J Nanomedicine. 2013;8:2375-2384.

43. Wang P, Wang X, Wang L, Hou X, Liu W, Chen C. Interaction of gold nanoparticles with proteins and cells. Sci Technol Adv Mater. 2015;16(3): $1-15$.

44. Sindhu K, Rajaram A, Sreeram KJ, Rajaram R. Curcumin conjugated gold nanoparticle synthesis and its biocompatibility. RSC Adv. 2014;4(4): 1808-1818.

45. Binupriya AR, Sathishkumar M, Vijayaraghavan K, Yun SI. Bioreduction of trivalent aurum to nano-crystalline gold particles by active and inactive cells and cell-free extract of Aspergillus oryzae var viridis. J Hazard Mater. 2010;177(1-3):539-545.

46. Lin L, Wu W, Huang J, et al. Catalytic gold nanoparticles immobilized on yeast: from biosorption to bioreduction. Chem Eng J. 2013; 225(3):857-864.
47. Hua Y, Narumi I, Gao G, et al. PprI: a general switch responsible for extreme radioresistance of Deinococcus radiodurans. Biochem Biophys Res Commun. 2003;306(2):354-360.

48. Khairnar NP, Misra HS, Apte SK. Pyrroloquinoline-quinone synthesized in Escherichia coli by pyrroloquinoline-quinone synthase of Deinococcus radiodurans plays a role beyond mineral phosphate solubilization. Biochem Biophys Res Commun. 2003;312(2):303-308.

49. Xie J, Zheng Y, Ying JY. Protein-directed synthesis of highly fluorescent gold nanoclusters. J Am Chem Soc. 2009;131(3):888-889.

50. Kumari M, Mishra A, Pandey S, et al. Physico-chemical condition optimization during biosynthesis lead to development of improved and catalytically efficient gold nano particles. Sci Rep. 2016;6:27575.

51. Ahmad T, Wani IA, Manzoor N, Ahmed J, Asiri AM. Biosynthesis, structural characterization and antimicrobial activity of gold and silver nanoparticles. Colloids Surf B Biointerfaces. 2013;107:227-234.

52. Radzig MA, Nadtochenko VA, Koksharova OA, Kiwi J, Lipasova VA, Khmel IA. Antibacterial effects of silver nanoparticles on gram-negative bacteria: influence on the growth and biofilms formation, mechanisms of action. Colloid Surf B Biointerfaces. 2013;102:300-306.

53. Soenen SJ, Rivera-Gil P, Montenegro JM, Parak WJ, De Smedt SC, Braeckmans K. Cellular toxicity of inorganic nanoparticles: common aspects and guidelines for improved nanotoxicity evaluation. Nano Today. 2011;6(5):446-465.

54. Patra JK, Baek KH. Novel green synthesis of gold nanoparticles using Citrullus lanatus rind and investigation of proteasome inhibitory activity, antibacterial, and antioxidant potential. Int J Nanomedicine. 2015; 10:7253-7264.

55. Nel AE, Mädler L, Velegol D, et al. Understanding biophysicochemical interactions at the nano-bio interface. Nat Mater. 2009;8(7):543-557.

56. Du L, Suo S, Wang G, et al. Mechanism and cellular kinetic studies of the enhancement of antioxidant activity by using surface-functionalized gold nanoparticles. Chemistry. 2013;19(4):1281-1287.

57. Cai W, Gao T, Hong H, Sun J. Applications of gold nanoparticles in cancer nanotechnology. Nanotechnol Sci Appl. 2008;2008(1):17-32.

58. Fratoddi I, Venditti I, Cametti C, Russo MV. How toxic are gold nanoparticles? The state-of-the-art. Nano Res. 2015;8(6):1771-1799. 


\section{Supplementary materials}

A

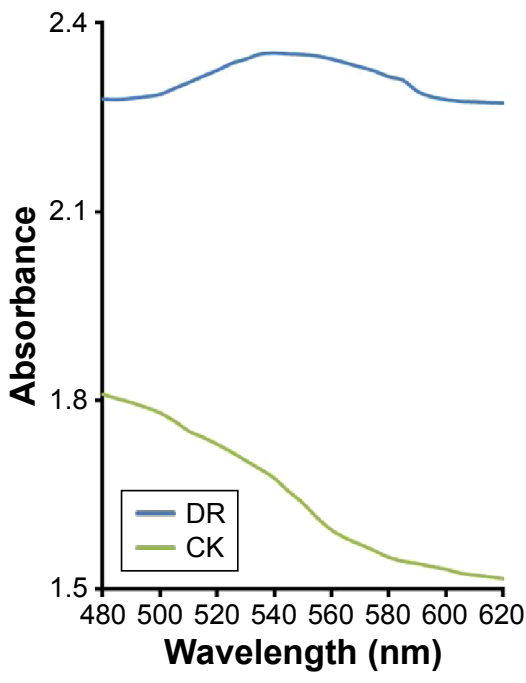

B

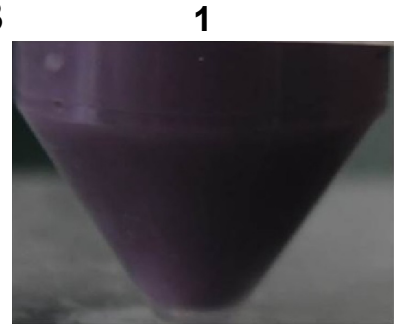

2

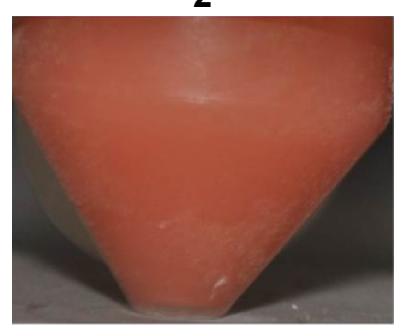

C

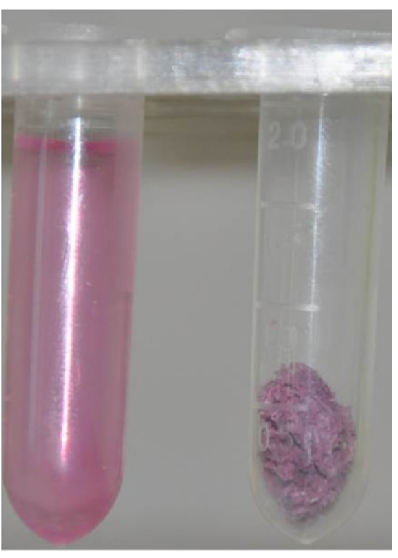

Figure SI Formation of AuNPs by Deinococcus radiodurans cell pellets in the presence of $\mathrm{Au}(\mathrm{III})$.

Notes: (A) The absorbance spectra of $D$. radiodurans cells (DR) in the presence of I mM Au(III) and the control (CK, D. radiodurans cells in the absence of Au(III)). (B) The color of $D$. radiodurans pellets with (I) or (2) without I mM Au(III). (C) The prepared AuNPs from the supernatant of $D$. radiodurans cells in the presence of Au(III). Left, supernatant; right, purified AuNPs powder obtained by dialysis and lyophilization of the supernatant.

Abbreviation: AuNPs, gold nanoparticles.

Table SI List of bacteria that synthesize gold nanoparticles

\begin{tabular}{|c|c|c|c|}
\hline Name of the bacteria & Saturation time/conditions & Localization/morphology/size & References \\
\hline Deinococcus radiodurans $\mathrm{RI}$ & $8 \mathrm{~h} ; 32^{\circ} \mathrm{C}, \mathrm{pH} 7, \mathrm{I} \mathrm{mM} \mathrm{Au}(\mathrm{III})$ & $\begin{array}{l}\text { Cell envelope, the cytosol and extracellular; } \\
\text { spherical and irregular shapes; } 43.75 \pm 0.56 \mathrm{~nm}\end{array}$ & This study \\
\hline Escherichia coli DH5 $\alpha$ & $120 \mathrm{~h} ; 25^{\circ} \mathrm{C} \pm 3^{\circ} \mathrm{C}, \mathrm{I} \mathrm{mM} \mathrm{Au}(\mathrm{III})$ & Cell surface; spherical; $20 \mathrm{~nm}$ & I \\
\hline Geobacillus strain IDI7 & 16 h; $65^{\circ} \mathrm{C}, \mathrm{pH} 7,1 \mathrm{mM} \mathrm{Au}(\mathrm{III})$ & Quasi-hexagonal; 5-50 and I0-20 nm & 2 \\
\hline Rhodopseudomonas capsulata & 48 h; pH 7, I mM Au(III) & Spherical; I0-20 nm & 3 \\
\hline Escherichia coli $\mathrm{KI} 2$ & $24 \mathrm{~h} ; 27^{\circ} \mathrm{C}, \mathrm{pH} 2.8,0.01 \mathrm{MAu}(\mathrm{III})$ & Circular; $50 \mathrm{~nm}$ & 4 \\
\hline Shewanella oneidensis & $48 \mathrm{~h} ; 30^{\circ} \mathrm{C}, \mathrm{I} \mathrm{mM} \mathrm{Au}(\mathrm{III})$ & Spheres; 2-50 nm & 5 \\
\hline Brevibacterium casei & $24 \mathrm{~h} ; 37^{\circ} \mathrm{C}, \mathrm{I} \mathrm{mM} \mathrm{Au}(\mathrm{III})$ & Spherical shape; $10-50 \mathrm{~nm}$ & 6 \\
\hline Cupriavidus metallidurans & $\mathrm{I} 44 \mathrm{~h} ; 30^{\circ} \mathrm{C}, \mathrm{pH} 7,50 \mu \mathrm{M} \mathrm{Au}(\mathrm{III})$ & Cytoplasm, periplasm; $100 \mathrm{~nm}$ & 7 \\
\hline Pseudomonas aeruginosa & $24 \mathrm{~h} ; 37^{\circ} \mathrm{C}, \mathrm{I} \mathrm{mM} \mathrm{Au}(\mathrm{III})$ & Extracellular; $15-30 \mathrm{~nm}$ & 8 \\
\hline Bacillus megaterium & $48 \mathrm{~h} ; 37^{\circ} \mathrm{C}, \mathrm{pH} 4.5, \mathrm{I} \mathrm{mMAu}(\mathrm{III})$ & Spherical; 4-36 nm & 9 \\
\hline
\end{tabular}

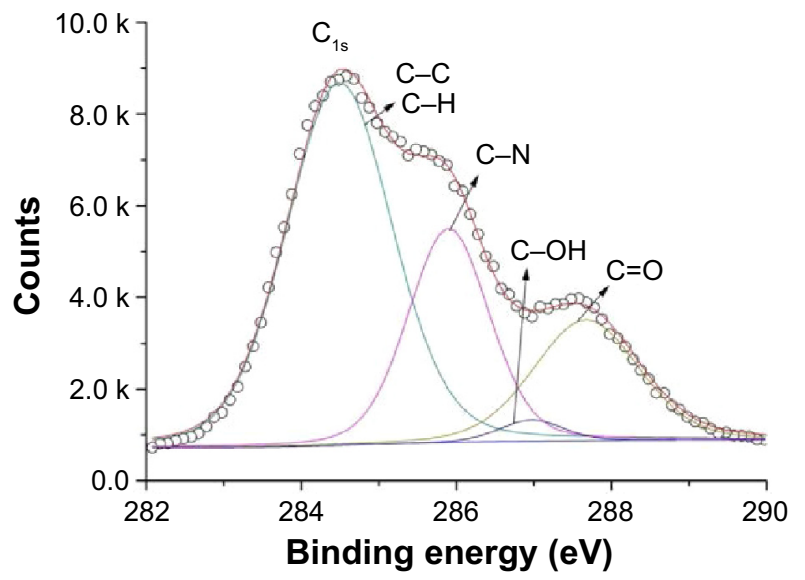

Figure S2 XPS spectrum of the core level of $C_{1 s}$ in the purified AuNPs.

Notes: The $\mathrm{C}_{1 \mathrm{~s}}$ spectrum could be resolved into four components that can bind to nanoparticle surface, consistent with previous reports. ${ }^{10,11}$ The peak at binding energies at $284.6 \mathrm{eV}$ corresponded to $\mathrm{C}-\mathrm{C}$ and $\mathrm{C}-\mathrm{H}$. Carbon bonded with nitrogen $(\mathrm{C}-\mathrm{N})$ and hydroxyl groups $(\mathrm{C}-\mathrm{OH})$ had binding energies at 285.6 and $286.7 \mathrm{eV}$, respectively. The peak at $287.8 \mathrm{eV}$ was attributed to carbonyl groups.

Abbreviations: XPS, X-ray photoelectron spectroscopy; AuNPs, gold nanoparticles. 


\section{References}

1. Du L, Jiang H, Liu X, Wang E. Biosynthesis of gold nanoparticles assisted by Escherichia coli $\mathrm{DH} 5 \alpha$ and its application on direct electrochemistry of hemoglobin. Electrochem Commun. 2007;9(5):1165-1170.

2. Correa-Llantén DN, Muñoz-Ibacache SA, Castro ME, Muñoz PA, Blamey JM. Gold nanoparticles synthesized by Geobacillus sp. strain ID17 a thermophilic bacterium isolated from Deception Island, Antarctica. Microb Cell Fact. 2013;12:75.

3. He S, Guo Z, Zhang Y, et al. Biosynthesis of gold nanoparticles using the bacteria Rhodopseudomonas capsulata. Mater Lett. 2007;61(18): 3984-3987.

4. Srivastava SK, Yamada R, Ogino C, Kondo A. Biogenic synthesis and characterization of gold nanoparticles by Escherichia coli $\mathrm{K} 12$ and its heterogeneous catalysis in degradation of 4-nitrophenol. Nanoscale Res Lett. 2013;8(1):70.

5. Suresh AK, Pelletier DA, Wang W, et al. Biofabrication of discrete spherical gold nanoparticles using the metal-reducing bacterium Shewanella oneidensis. Acta Biomater. 2011;7(5):2148-2152.

6. Kalishwaralal K, Deepak V, Ram Kumar Pandian S, et al. Biosynthesis of silver and gold nanoparticles using Brevibacterium casei. Colloids Surf B Biointerfaces. 2010;77(2):257-262.
7. Reith F, Etschmann B, Grosse C, et al. Mechanisms of gold biomineralization in the bacterium Cupriavidus metallidurans. Proc Natl Acad Sci U S A. 2009; 106(42):17757-17762.

8. Husseiny MI, El-Aziz MA, Badr Y, Mahmoud MA. Biosynthesis of gold nanoparticles using Pseudomonas aeruginosa. Spectrochim Acta A Mol Biomol Spectrosc. 2007;67(3-4):1003-1006.

9. Jena S, Das B, Bosu R, Suar M, Mandal D. Bacteria generated antibacterial gold nanoparticles and potential mechanistic insight. J Cluster Sci. 2015;26(5):1-15.

10. Das SK, Dickinson C, Lafir F, Brougham DF, Marsili E. Synthesis, characterization and catalytic activity of gold nanoparticles biosynthesized with Rhizopus oryzae protein extract. Green Chem. 2012;14(5): $1322-1334$

11. Das SK, Liang J, Schmidt M, Laffir F, Marsili E. Biomineralization mechanism of gold by zygomycete fungi Rhizopous oryzae. ACS Nano. 2012;6(7):6165-6173.
International Journal of Nanomedicine

\section{Publish your work in this journal}

The International Journal of Nanomedicine is an international, peerreviewed journal focusing on the application of nanotechnology in diagnostics, therapeutics, and drug delivery systems throughout the biomedical field. This journal is indexed on PubMed Central, MedLine, CAS, SciSearch ${ }^{\circledR}$, Current Contents ${ }^{\circledR} /$ Clinical Medicine,

\section{Dovepress}

Journal Citation Reports/Science Edition, EMBase, Scopus and the Elsevier Bibliographic databases. The manuscript management system is completely online and includes a very quick and fair peer-review system, which is all easy to use. Visit http://www.dovepress.com/ testimonials.php to read real quotes from published authors. 